\title{
Glosa aprobująca do wyroku Naczelnego Sądu Administracyjnego z dnia 21 stycznia 2015 r., II GSK 2252/13
}

\section{Tezy:}

1. Rada Miejska B. jako organ stanowiący jednostki samorządu terytorialnego w przypadku, gdy na jej terenie nie ma publicznej szkoły danego typu i rodzaju w rozumieniu art. 90 ust. 3 zdanie 2 ustawy z dnia 7 września 1991 r. o systemie oświaty - jest zobowiązana do określenia kryteriów (sposobu) wyboru najbliższej gminy, której wydatki bieżące na prowadzenie szkoły publicznej danego typu lub rodzaju będą stanowiły podstawę do ustalenia wysokości dotacji. Wynika to z art. 90 ust. 4 u.s.o., na mocy którego ustawodawca obliguje organ stanowiący jednostki samorządu terytorialnego do określenia m.in. trybu udzielania dotacji, z uwzględnieniem w szczególności podstawy obliczania dotacji. Wybór najbliższej gminy, która dostarcza danych porównawczych, ma bowiem bezpośredni wpływ na ustalenie wysokości dotacji, a tym samym na jej ostateczną kwotę. 
2. Z art. 90 ust. 4 u.s.o. wynika, że intencją ustawodawcy było przeniesienie na rzecz organu stanowiącego właściwej jednostki samorządu terytorialnego uprawnienia do ustalenia, w drodze uchwały (stanowiącej akt prawa miejscowego), ogólnych zasad związanych z procesem przyznawania dotacji oświatowych oraz trybu weryfikacji prawidłowości wykorzystania przyznawanych środków. Przeniesienie przez ustawodawcę omawianych kompetencji na jednostkę samorządu terytorialnego nie jest przypadkowe. Ma ono służyć sprecyzowaniu i indywidualizacji trybu przyznawania i rozliczania dotacji w odniesieniu do potrzeb konkretnej społeczności, uwzględniając specyfikę lokalną, w granicach określonych przepisami ustawy.

\section{1.}

Glosowany wyrok zasługuje na uwagę nie tylko ze względu na przedmiot rozpatrywanej przez NSA skargi kasacyjnej, którą był wyrok WSA oddalający skargę na uchwałę Rady Miejskiej w sprawie trybu udzielania dotacji oświatowych, ale także ze względu na sformułowaną w jego uzasadnieniu wykładnię ustawowej delegacji do wydawania aktów prawa miejscowego przez organ stanowiący jednostki samorządu terytorialnego (dalej: j.s.t.) oraz charakteru prawnego tych aktów. Ponadto tezy sformułowane w uzasadnieniu glosowanego wyroku stały się niezwykle symboliczne w świetle ostatniej nowelizacji ${ }^{1}$ ustawy o systemie oświaty (dalej: u.s.o. $)^{2}$, wprowadzającej m.in. zmianę brzmienia przepisów delegacyjnych art. 80 ust. 4 i art. 90 ust. 4 u.s.o. Zmiana ta, choć miała niewielki zakres (polegający na dodaniu słowa „pobrania”), spowodowała, że ustawodawca postanowił sformułować w ustawie nowelizacyjnej również przepis intertemporalny (art. 34) odnoszący się do oświatowych uchwał dotacyjnych podjętych przez organy stanowiące j.s.t. przed 31 marca 2015 r. Ta jakże znamienna reguła walidacyjna odnosząca się do aktów prawa

1 Ustawa z dnia 20 lutego 2015 r. o zmianie ustawy o systemie oświaty oraz niektórych innych ustaw (Dz.U. z 2015 r. poz. 357), dalej: nowelizacja u.s.o. z 2015 r.

2 Ustawa z dnia 7 września 1991 r. o systemie oświaty (tekst jedn. Dz.U. z 2004 r. Nr 256, poz. 2572). 
miejscowego $^{3}$ (postanawiająca o utracie mocy ich obowiązywania z dniem 31 grudnia 2015 r.) świadczy o traktowaniu powyższych uchwał przez ustawodawcę przede wszystkim jako aktów wykonawczych do u.s.o. o charakterze zbliżonym do rozporządzeń ministerialnych. Nadawanie jednak tym uchwałom ściśle wykonawczego charakteru powinno konsekwentnie prowadzić do radykalnej zmiany normy upoważniającej do ich wydania tak, aby spełniała standardy upoważnienia do wydania rozporządzenia określone w art. 92 Konstytucji RP, a więc była upoważnieniem bardziej szczegółowym, zawierającym wytyczne co do treści aktu ${ }^{4}$. Tymczasem normy upoważniające sformułowane w art. 80 ust. 4 i art. 90 ust. 4 u.s.o. mają nadal raczej charakter generalny (blankietowy) niż wykonawczy, natomiast uchwały podejmowane na ich podstawie przez rady gmin i powiatów konsekwentnie mają nadal charakter aktów prawa miejscowego. W przypadku tych uchwał zaobserwować więc można zbyt silną sprzeczność (,zderzenie”) między ich bezsprzecznie wykonawczym charakterem a swobodą lokalnego prawodawcy określoną w art. 94 Konstytucji RP. Glosowany wyrok NSA w pełni uwzględnia tą sprzeczność, oddalając większość zarzutów skarżącego kasacyjnie wobec uchwały Rady Miejskiej w sprawie trybu udzielania dotacji oświatowych (tym samym uznając swobodę lokalnego prawodawcy w tym zakresie, ograniczoną jedynie zakresem delegacji ustawowej) oraz akceptując jeden z nich (tym samym uznając wykonawczy charakter powyższej uchwały).

Rozstrzygnięcie oraz uzasadnienie glosowanego wyroku NSA jest przykładem racjonalnego zrównoważenia praw i obowiązków obu stron stosunku dotacyjnego, jakimi są - gmina (jako organ dotujący) oraz spółka prowadząca niepubliczne szkoły (jako beneficjent dotacji). Naczelny Sąd Administracyjny, uchylając zaskarżony wyrok i przekazując go do ponownego rozpoznania WSA, uznał argumentację skarżącej kasacyjnie Spółki

3 O sytuacjach intertemporalnych i regule walidacyjnej w odniesieniu jednak do obowiązywania przepisów ustaw i rozporządzeń (nie zaś aktów prawa miejscowego) zob. szerzej: S. Wronkowska, M. Zieliński, Komentarz do Zasad techniki prawodawczej z dnia 20 czerwca 2002 r., Warszawa 2012, s. 82-92.

4 O różnicach między upoważnieniem do stanowienia rozporządzeń a upoważnieniem do stanowienia aktów prawa miejscowego zob. szerzej: D. Dąbek, Prawo miejscowe, Warszawa 2007, s. 93-99. 
jako organu prowadzącego niepubliczne szkoły w odniesieniu do jednego zarzutu wobec uchwały Rady Miejskiej - mianowicie braku sprecyzowania w tej uchwale pojęcia „najbliższa gmina”, której wydatki mają być podstawą ustalania dotacji oświatowej. W odniesieniu do pozostałych postanowień uchwały Rady Miejskiej, NSA potwierdził rozstrzygnięcie WSA oddalające skargę Spółki, tym samym przychylając się do szerszych uprawnień organu stanowiącego j.s.t. w zakresie ustanawiania aktów prawa miejscowego, jakim są uchwały podejmowane na podstawie art. 90 ust. 4 u.s.o.

\section{2.}

W rozpatrywanej przez NSA sprawie Spółka z o.o. w L. prowadząca na terenie miasta B. szkoły niepubliczne świadczące usługi edukacyjne (dalej: Spółka) wniosła do WSA w Gliwicach skargę na uchwałę Rady Miasta B. z dnia 19 grudnia 2012 r. w sprawie ustalenia trybu udzielania i rozliczania dotacji dla prowadzonych na terenie miasta B. niepublicznych szkół, przedszkoli i innych form wychowania przedszkolnego oraz trybu i zakresu kontroli prawidłowości ich wykorzystania, domagając się stwierdzenia nieważności jej poszczególnych postanowień. Skarżąca Spółka prowadziła na terenie Miasta B. szkoły niepubliczne o uprawnieniach szkół publicznych niewymienionych w ust. 2a art. 90 u.s.o., a więc szkoły, w których nie jest realizowany obowiązek szkolny lub obowiązek nauki. Spółce, jako organowi prowadzącemu powyższe szkoły, przysługiwały dotacje z budżetu Miasta B. na podstawie art. 90 ust. 3 u.s.o. ${ }^{5} \mathrm{~W}$ swojej skardze na uchwałę Rady Miasta B. Spółka wskazywała, iż większość spornych jej postanowień przekraczało ustawowe upoważnienie z art. 90 ust. 4 u.s.o., zaś w przypadku jednego postanowienia (zawierającego po-

5 Przepis ten stanowi, że szkołom tym przysługują dotacje na każdego ucznia uczestniczącego w co najmniej 50\% obowiązkowych zajęć edukacyjnych w danym miesiącu w wysokości nie niższej niż 50\% ustalonych w budżecie odpowiednio danej gminy lub powiatu wydatków bieżących ponoszonych w szkołach publicznych tego samego typu i rodzaju w przeliczeniu na jednego ucznia. Dalej przepis ten stwierdza, iż w przypadku braku na terenie gminy lub powiatu szkoły publicznej danego typu i rodzaju podstawą do ustalenia wysokości dotacji są wydatki bieżące ponoszone przez najbliższą gminę lub powiat na prowadzenie szkoły publicznej danego typu lub rodzaju. 
jęcie „najbliższa gmina”) sformułowała zarzut niewykonania w pełni ustawowego upoważnienia nakazującego uregulowanie trybu udzielania dotacji oświatowej - poprzez brak określenia w uchwale kryteriów wyboru najbliższej gminy, której wydatki bieżące na prowadzenie szkoły publicznej danego typu i rodzaju będą podstawą do ustalenia wysokości dotacji.

Wśród postanowień uchwały Rady Miasta B. naruszających prawo Spółka wymieniła:

- $\quad$ § 4 ust. 1 pkt 3, w którym Rada Miasta stwierdziła, że osoba prowadząca szkołę, przedszkole lub inną formę wychowania przedszkolnego zobowiązana jest do prowadzenia odrębnej ewidencji wydatków finansowanych z dotacji;

- $\quad \S 7$ ust. 4, w którym Rada Miasta postanowiła, że w przypadku braku na terenie miasta B. szkoły publicznej danego typu i rodzaju, o których mowa w § 2 punkt 3 uchwały, podstawą do ustalenia wysokości dotacji są wydatki bieżące ponoszone przez najbliższą gminę na prowadzenie szkoły publicznej danego typu;

- $\quad$ § 9 ust. 1, w którym postanowiono, że po przekazaniu pierwszej raty dotacji warunkiem przekazania kolejnych rat jest złożenie przez osobę prowadzącą szkołę, przedszkole lub inną formę wychowania przedszkolnego organowi dotującemu w terminie do 15 . dnia następnego miesiąca informacji o rzeczywistej liczbie uczniów objętych dotacją za dany miesiąc oraz wykazu uczniów;

- $\quad$ § 9 ust. 2, w którym Rada Miejska stwierdziła, że w przypadku zakończenia działalności przez szkołę, przedszkole lub inną formę wychowania przedszkolnego osoba prowadząca powinna przekazać niezwłocznie organowi dotującemu ostateczne rozliczenie wykorzystania dotacji, a w przypadku wystąpienia nadpłaty dotacji dokonać zwrotu w terminie 30 dni od daty zakończenia działalności;

- $\quad \S 12$ ust. 1 i 2, w którym Rada Miejska ustanowiła zasady i przesłanki dokonywania zwrotów dotacji modyfikując przepisy ustawy o finansach publicznych (art. 251 i 252) obowiązujące w tym zakresie. Postanowiono bowiem, że zwrotowi do budżetu miasta podlega dotacja: pobrana w nadmiernej wysokości, niewykorzystana - nierozli- 
czona dowodem poniesienia wydatków bieżących, wykorzystana niezgodnie z przeznaczeniem na pokrycie innych wydatków niż określone w art. 90 ust. 3d ustawy o systemie oświaty, rozliczona niewłaściwie, niezgodnie ze stanem faktycznym (ust. 1), a także, iż zwrot dotacji następuje w ciągu 15 dni od dnia stwierdzenia okoliczności wraz z odsetkami naliczonymi jak dla zaległości podatkowych (ust. 2).

W odpowiedzi na skargę, organ dotujący - Miasto B. reprezentowane przez Prezydenta Miasta - wniosło o jej oddalenie. Odpierając zarzuty skarżącej Spółki sformułowane w odniesieniu do poszczególnych przepisów uchwały, Miasto B. argumentowało, że zobowiązanie podmiotu dotowanego do prowadzenia odrębnej ewidencji wydatków finansowanych dotacją oraz do składania miesięcznych rozliczeń dotacji wraz z wykazem uczniów, warunkujących przekazanie kolejnej części dotacji, wynika z uprawnień kontrolnych j.s.t., które zostały ustanowione w art. 90 ust. 3e-3g u.s.o., a także z obowiązku kontrolowania przez j.s.t. wykorzystania środków dotacyjnych przez podmiot dotowany, zgodnie z celami określonymi w art. 90 ust. 3d u.s.o. W zakresie postanowień § 12 ust. 1 i 2 uchwały, Miasto B. wskazywało, iż nie doszło w nich do modyfikacji zapisów ustawowych art. 251 i 252 u.f.p. dotyczącego zasad zwrotu do budżetu miasta dotacji. W orzecznictwie sądowo-administracyjnym wyrażany zaś jest pogląd, że niekiedy konieczne jest przytoczenie w uchwale rady gminy zapisów ustawowych, jeżeli dzięki takiemu zabiegowi akt prawa miejscowego staje się czytelny i zrozumiały. W odniesieniu natomiast do pojęcia „najbliższej gminy lub powiatu” (zastosowanego w § 7 ust. 4 uchwały) Miasto B., powołując się na wyrok WSA w Kielcach z dnia 14 grudnia 2009 r. ( II SA/Ke 657/09), stwierdziło, że użyte w art. 90 ust. 3 u.s.o. określenie „przez najbliższą gminę lub powiat” w liczbie pojedynczej wskazuje, że podstawę do ustalenia dotacji stanowią wydatki bieżące ponoszone tylko w jednej gminie lub powiecie. Skoro ustawodawca nie zamieścił w art. 90 ust. 3 u.s.o. kryteriów „najbliższego powiatu”, to respektując zasadę samodzielności gminy, wyrażoną w art. 165 ust. 2 Konstytucji RP, pozostawił organom samorządu swobodę w ustalaniu wysokości dotacji dla szkół, z uwzględnieniem sytuacji ekonomicznej miasta. 
WSA w Gliwicach oddaliło skargę Spółki, akceptując powyższą argumentację Miasta B. z przywołaniem dodatkowo orzecznictwa zapadłego w tym zakresie. Spółka złożyła do NSA skargę kasacyjną od powyższego wyroku, wnosząc o jego uchylenie i przekazanie sprawy do ponownego rozpoznania oraz zasądzenie kosztów postępowania.

W odniesieniu do postanowienia uchwały zobowiązującego podmiot prowadzący szkołę do prowadzenia odrębnej ewidencji wydatków finansowanych środkami z dotacji (§ 4 ust. 1 pkt 3), Spółka argumentowała, że rozliczenie dotacji pozostaje w związku z liczbą uczniów i jedyną dopuszczalną formą kontroli przyznawanych dotacji może być rozliczenie faktycznej liczby uczniów, na których są przyznawane dotacje. W zakresie zaś § 7 ust. 4 uchwały posługującego się pojęciem „najbliższa gmina”, pełnomocnik Spółki wskazywał, że w komentowanym zapisie brak jest wskazania przez organ stanowiący sposobu i kryteriów wyboru najbliższej gminy prowadzącej szkoły publiczne, których wydatki powinny być podstawą obliczenia dotacji dla szkół niepublicznych. Wskazane zaniechanie, zdaniem skarżącej, może powodować, że decyzje w tym przedmiocie będą podejmowane przez organy wykonawcze, które nie posiadają do tego ustawowych kompetencji. Co do zaś postanowienia uchwały zobowiązującej podmiot prowadzący szkołę do składania miesięcznych informacji o rzeczywistej liczbie uczniów objętych dotacją oraz wykazu uczniów (§ 9 ust. 1) pełnomocnik Spółki, zarzucając nielegalność tego przepisu uchwały, stwierdził, że został on uchwalony z przekroczeniem granic upoważnienia ustawowego wynikającego z art. 90 ust. 4 u.s.o. Zdaniem Pełnomocnika informacje o rzeczywistej liczbie uczniów uczęszczających do szkoły za dany miesiąc oraz wykaz uczniów warunkują jedynie wysokość kolejnych dotacji i mogą być elementem trybu jej przyznawania, nie mogą jednak stanowić przesłanki przekazania kolejnych rat dotacji. Niewywiązanie się z obowiązku złożenia żądanych informacji nie może być sankcjonowane wstrzymaniem dotacji. W zakresie natomiast § 9 ust. 2 uchwały (regulującego przypadek zakończenia działalności przez szkołę oraz obowiązek przekazania organowi dotującemu ostatecznego rozliczenia wykorzystania dotacji oraz dokonania zwrotu nadpłaty dotacji), skarżąca Spółka wskazywała, że pojęcie „nadpłata dota- 
cji” nie występuje w przepisach powszechnie obowiązującego prawa, a beneficjent dotacji zobowiązany jest do zwrotu dotacji na podstawie z art. 252 u.f.p. po przeprowadzeniu postępowania administracyjnego. W przepisach ustawowych brak jest także uregulowań związanych z procedurą postępowania w przypadku zakończenia działalności przez szkołę, w związku z czym organ dotujący nie posiada upoważnienia do wydania przepisów w tym zakresie. Na art. 252 u.f.p. skarżąca Spółka powoływała się również podnosząc zarzut sprzeczności z tym przepisem postanowień § 12 ust. 1 i 2 uchwały. Skarżąca Spółka wskazywała, iż powyższymi postanowieniami Rada Miejska naruszyła art. 252 u.f.p. poprzez uregulowanie odmiennej procedury zwrotu dotacji do budżetu jednostki samorządu terytorialnego oraz poprzez rozszerzenie katalogu przesłanek warunkujących zwrot dotacji do budżetu jednostki samorządu terytorialnego.

\section{3.}

Rozpatrując skargę kasacyjną, NSA orzekł, że zasługuje ona na uwzględnienie, ale nie wszystkie zarzuty w niej zawarte były uzasadnione. Większość z tych zarzutów NSA (podobnie jak sąd I instancji) uznał za bezzasadne, natomiast przekazał sprawę do ponownego rozpoznania przez WSA w Gliwicach w odniesieniu do jednego zarzutu sformułowanego wobec treści § 7 ust. 4 zaskarżonej uchwały, posługującego się niedookreślonym zwrotem „najbliższa gmina”. Na marginesie należy wspomnieć, iż WSA w Gliwicach, rozpoznając sprawę ponownie, 18 maja 2015 r. stwierdził nieważność § 7 ust. 4 zaskarżonej uchwały, a w pozostałym zakresie skargę oddalił ${ }^{6}$. Wobec faktu niepodjęcia przez Radę Miasta B. nowej uchwały w sprawie trybu udzielania dotacji oświatowych lub uchwały zmieniającej obecną uchwałę, aktualna sytuacja w zakresie procesu dotowania niesamorządowych jednostek oświaty (odnosząca się do pojęcia „najbliższa gmina”) w zasadzie pozostaje bez zmian, gdyż oznacza to, że ma tu bezpośrednie zastosowanie przepis art. 90 ust. 3 u.s.o., posługujący się również niedo-

6 Zob. wyrok WSA w Gliwicach z dnia 18 maja 2015 r., I SA/Gl 335/15, Centralna Baza Orzeczeń Sądów Administracyjnych (CBOSA). 
określonym zwrotem „najbliższa gmina”. W konsekwencji obecna praktyka stosowana w Mieście B. w zakresie interpretacji zwrotu „najbliższa gmina” sprowadza się do tego, że nadal to organ wykonawczy Miasta B. dokonuje wyboru tej gminy w ramach swych „obliczeniowych” kompetencji wykonawczych. Praktyka ta jest zresztą przyjmowana w większości gmin w Polsce, które kierują się w tym zakresie orzeczeniami sądów administracyjnych $^{7}$, przyznającymi organowi wykonawczemu j.s.t. kompetencję wyboru „najbliższej gminy” przy naliczaniu dotacji danej jednostce oświatowej, tym samym akceptując brak skonkretyzowania pojęcia „najbliższa gmina” w oświatowej uchwale dotacyjnej.

Zagadnienie interpretacji pojęcia „najbliższa gmina” (zastosowanego przez ustawodawcę nie tylko w art. 90 ust. 3, ale też w art. 90 ust. 2b, 80 ust. 2 i 2 b u.s.o.) jest dobrym przykładem na analizę charakteru i zakresu norm upoważniających art. 80 ust. 4 i art. 90 ust. 4 u.s.o., a także na dokonanie podziału kompetencji organów j.s.t. (stanowiącego i wykonawczego) w procesie dotowania niesamorządowych jednostek oświaty. Wymienione wyżej normy upoważniające należą do kategorii upoważnień szczegółowych zawartych w ustawach szczególnych, na podstawie których organy j.s.t. stanowią ,akty prawa miejscowego o charakterze wykonawczym”. Jak wskazuje D. Dąbek, akty te są „wydawane na mocy i w granicach szczególnej delegacji ustawowej (...). Mają one za zadanie uszczegóławiać ustawy, normując zagadnienia techniczne z uwzględnieniem specyfiki lokalnej społeczności oraz warunków i potrzeb miejscowych. Są więc przepisami o wykonawczym charakterze w tym znaczeniu, że wypełniają normatywnymi treściami luzy pozostawione w regulacji ustawowej między innymi po to, by można było uwzględnić specyfikę terenową”. Na taki też charakter oświatowych uchwał dotacyjnych wskazuje NSA w uzasadnieniu glosowanego wyroku. NSA wskazał bowiem, iż „ustawodawca przekazując prawodawcy podustawowemu (organowi stanowiącemu jednostki samorządu terytorialnego) regulację określonej materii, pozostawił mu pewien margines swobody, aby ten mógł osiągnąć zamierzony cel jak najmniejszym

Zob.: wyrok NSA z dnia 21 grudnia 2004 r., GSK 1187/04, wyrok WSA w Gliwicach z dnia 21 października 2014 r., I SA/Gl 26/14, wyrok WSA w Łodzi z dnia 3 kwietnia 2014 r., I SA/Łd 127/14. 
kosztem dla adresatów tych przepisów. Przeniesienie przez ustawodawcę omawianych kompetencji na jednostkę samorządu terytorialnego nie jest przypadkowe. Ma ono służyć sprecyzowaniu i indywidualizacji trybu przyznawania i rozliczania dotacji w odniesieniu do potrzeb konkretnej społeczności, uwzględniając specyfikę lokalną, w granicach określonych przepisami ustawy”.

Kierując się powyższymi cechami aktów prawa miejscowego, NSA w rozpatrywanej sprawie słusznie oddalił zarzuty skarżącej Spółki odnoszące się do postanowień uchwały Rady Miejskiej B. mające ściśle wykonawczy i „trybowy” charakter. Skoro bowiem organ stanowiący j.s.t., zgodnie $\mathrm{z}$ delegacją $\mathrm{z}$ art. 90 ust. 4 u.s.o. ma ustalić tryb udzielania i rozliczania dotacji oraz tryb i zakres kontroli prawidłowości ich wykorzystania, uwzględniając w szczególności podstawę obliczenia dotacji, zakres danych, które powinny być zawarte we wniosku o udzielenie dotacji i w rozliczeniu jej wykorzystania, oraz termin i sposób rozliczenia dotacji - to jest oczywiste, że Rada Miejska B. w oświatowej uchwale dotacyjnej mogła ustalić, że: - podmiot dotowany jest zobowiązany do prowadzenia odrębnej ewidencji wydatków finansowanych dotacją - gdyż ma to służyć przeprowadzeniu skutecznej kontroli wykorzystania środków dotacyjnych,

- $\quad$ warunkiem przekazania kolejnej części dotacji jest złożenie przez podmiot dotowany miesięcznego rozliczenia dotacji wraz z wykazem uczniów - gdyż stanowi to element trybu udzielania dotacji przyjęty w Mieście B., a także jest zgodny ze strukturą dotacji (podzieloną na 12 miesięcznych części), przyjętą $\mathrm{w}$ art. 90 ust. 3c u.s.o.,

- $\quad$ w przypadku zakończenia działalności podmiot dotowany powinien przekazać organowi dotującemu ostateczne rozliczenie wykorzystania dotacji, a w przypadku wystąpienia nadpłaty dotacji dokonać zwrotu w terminie 30 dni od daty zakończenia działalności - gdyż stanowi to element trybu rozliczania dotacji ustalony przez Radę Miejską B. dla sytuacji zakończenia działalności przez dotowany podmiot, której ustawodawca nie uregulował w przepisach u.s.o.

Słuszność utrzymania w mocy wymienionych wyżej postanowień uchwały Rady Miejskiej potwierdza dokonane ostatnio (wspomniane w pkt 1 glosy) rozszerzenie przepisów delegacyjnych art. 80 ust. 4 i art. 90 ust. 4 
u.s.o. poprzez dodanie wyrazu „pobrania”. Obecnie więc upoważnienie organu stanowiącego j.s.t. jest szersze, gdyż ma on uprawnienie i obowiązek określić w swej uchwale tryb i zakres kontroli prawidłowości nie tylko wykorzystania, ale i pobrania dotacji.

Pewne wątpliwości wzbudzać może jedynie oddalenie przez NSA zarzutu Spółki sformułowanego wobec § 12 ust. 1 i 2 uchwały, w których w istocie Rada Miejska B. dokonała modyfikacji zapisów ustawowych art. 251 i 252 u.f.p. regulujących zasady dokonywania zwrotów dotacji udzielanych z budżetu j.s.t. Obok czterech przesłanek zwrotu dotacji, uregulowanych w art. 251 i 252 u.f.p., Rada Miejska B. w swej uchwale: pominęła przesłankę nienależnego pobrania, dodała nową przesłankę (niewłaściwe rozliczenie dotacji, niezgodnie ze stanem faktycznym), a także sama zdefiniowała przesłankę niewykorzystania dotacji - stanowiąc, iż jest to dotacja nierozliczona dowodem poniesienia wydatków bieżących. Jak wskazuje się w orzecznictwie, „materia będąca przedmiotem regulacji prawnej w drodze uchwały rady gminy nie może być regulowana w odrębnych przepisach prawa powszechnie obowiązujących”8 . „Narusza powszechnie obowiązujący porządek prawny w stopniu istotnym nie tylko regulowanie przez gminę raz jeszcze tego, co zostało już zamieszczone w źródłach powszechnie obowiązującego prawa, lecz także modyfikowanie przepisu ustawowego przez akt wykonawczy niższego rzędu, co możliwe jest tylko w przepisach wyraźnie przewidzianego upoważnienia ustawowego"9. W rozpatrywanej przez NSA sprawie kwestią sporną pozostaje, czy Rada Miejska B., umieszczając w swej uchwale postanowienia $\$ 12$ ust. 1 i 2 regulujące zasady dokonywania zwrotów dotacji oświatowej, dokonała bezprawnej modyfikacji przepisów art. 251 i 252 u.f.p., czy też uczyniła to w ramach upoważnienia do miejscowego uregulowania trybu rozliczania dotacji. Uwzględniając fakt, iż modyfikacja ta w istocie nie niweluje (nie eliminuje) ustawowych przesłanek zwrotów dotacji, a także nie narusza ustawowych uprawnień i powinności podmiotu dotowanego (na co wskazuje NSA w swoim rozstrzygnięciu), należałoby się przychylić do drugiego z wyżej wymie-

8 Wyrok WSA we Wrocławiu z dnia 7 grudnia 2009 r., II SA/Wr 401/09, Lex nr 583193.

9 Uchwała RIO w Poznaniu z dnia 9 marca 2011 r., 5/424/2011, Dz.Urz. Województwa Wielkopolskiego z 2011 r. Nr 109, poz. 1852. 
nionych stanowisk, chociaż pogląd ten nie jest tożsamy ze stanowiskiem orzecznictwa RIO w tym zakresie ${ }^{10}$. Ponadto należy zauważyć, iż u.f.p. w ogóle nie reguluje jakże istotnej przesłanki zwrotu dotacji, którą jest nierozliczenie dotacji lub jej rozliczenie niezgodnie ze stanem faktycznym, w związku z czym zagadnieniem nadal wątpliwym jest pytanie, czy organ stanowiący j.s.t. może tę lukę uzupełnić w swej oświatowej uchwale dotacyjnej w ramach upoważnienia do ustalenia lokalnego trybu rozliczania dotacji. Zagadnieniem wciąż bowiem nierozwiązanym jest pytanie: co dotujący samorząd powinien uczynić, jeśli dotowana jednostka oświaty nie składa rozliczenia dotacji albo udaremnia i utrudnia wykonanie czynności kontrolnych dotyczących prawidłowości pobrania i wykorzystania dotacji ${ }^{11}$

Za precedensową decyzję NSA w rozpatrywanej sprawie należy uznać przychylenie się do zarzutu skarżącej Spółki odnoszącego się do braku sprecyzowania w uchwale Rady Miejskiej pojęcia „najbliższa gmina”. Decyzja ta pokrywa się ze stanowiskiem Najwyższej Izby Kontroli (odnoszącej się do pojęcia „najbliższy powiat”), która w informacji o wynikach kontroli przeprowadzonej w zakresie dotowania ponadgimnazjalnych szkół niepublicznych stwierdziła, iż „brak kryteriów ustalania znaczenia pojęcia «najbliższy powiat», pozwalał na praktycznie dowolną interpretację tego pojęcia przez organy wykonawcze powiatów (zarządy), co skutkowało uznaniowością i brakiem jednolitości w tym zakresie. Dobór najbliższego powiatu, z którego pochodziły dane porównawcze, miał bezpośredni wpływ na wysokość podstawy obliczania dotacji, a tym samym na ostateczną jej kwotę"12. NSA słusznie więc podzielił powyższe stanowisko NIK, a także stanowisko wyrażone w niektórych orzeczeniach NSA i WSA (będących

10 Zob. szerzej: P. Ciszewski, W. Lachiewicz, B. Jakacka, L. Lipiec-Warzecha, A. Pawlikowska, Dotacje oświatowe, Warszawa 2015, s. 182.

11 Nowelizacja u.s.o. z 2015 r. wprowadziła wprawdzie możliwość wstrzymywania przekazywania dotacji w przypadku udaremniania lub utrudniania czynności kontrolnych, lecz tylko w odniesieniu do szkół niepublicznych o uprawnieniach szkół publicznych, w których nie jest realizowany obowiązek szkolny lub obowiązek nauki (tzw. szkół dla dorosłych).

12 Informacja o wynikach kontroli, Finansowanie ponadgimnazjalnych szkół niepublicznych przez jednostki samorzq̨du terytorialnego województwa wielkopolskiego, Najwyższa Izba Kontroli, Warszawa 25 lipca 2012 r., www.nik.gov.pl, (dostęp: 30.08.2015 r.). 
W mniejszości) ${ }^{13}$, iż „,Z uwagi na brak definicji legalnej pojęcia «najbliższa gmina», nabiera ono cech pojęcia niedookreślonego, które na potrzeby każdej sprawy indywidualnej wymaga konkretyzacji”, a więc to organ stanowiący j.s.t., stanowiąc odpowiednie przepisy prawa miejscowego na podstawie art. 90 ust. 4 u.s.o., jest zobowiązany do sprecyzowania tego pojęcia. W większości orzecznictwa, a także w literaturze głoszony jest jednak pogląd, iż organ stanowiący takiego obowiązku nie ma, zaś wybór „najbliższej gminy lub powiatu” jest dokonywany przez organ wykonawczy j.s.t. w procesie stosowania prawa i w ramach jego kompetencji wykonawczych ${ }^{14}$. Trudno z tym poglądem się zgodzić, uwzględniając opisany wyżej wykonawczy i zarazem „lokalny” charakter aktów prawa miejscowego, stanowionych na podstawie upoważnień takich jak art. 90 ust. 4 u.s.o. Skoro więc z upoważnienia wynika, że rada gminy lub powiatu, określając tryb dotowania niesamorządowych jednostek oświaty, ma uwzględnić podstawę obliczania dotacji, zaś z charakteru aktu prawa miejscowego wynika, iż ma on uwzględniać lokalne uwarunkowania - to z pewnością brak na terenie danej j.s.t. szkoły danego typu i rodzaju jest lokalnym uwarunkowaniem, a więc organ stanowiący j.s.t. zobowiązanej do udzielenia dotacji powinien w swej uchwale sprecyzować „najbliższą gminę lub powiat”, której dane będą brane pod uwagę przy ustalaniu podstawy obliczania dotacji. Należy zauważyć, że takie działanie organu stanowiącego będzie również wyrazem jego samodzielności nie tylko prawodawczej, ale i finansowej, na którą powoływał się NSA w wyroku z dnia 21 grudnia 2004 r. $^{15}$, przyznając organowi wykonawczemu j.s.t. prawo samodzielnego wyboru „najbliższej gminy” (nawet tej, w której stawka dotacji jest najniższa), gdyż wynika to z zasady prowadzenia przez j.s.t. samodzielnej gospodarki finansowej.

13 Wyroki NSA: z dnia 23 kwietnia 2002 r., III SA 2080/01, NSA i z dnia 15 lutego 2006 r., II GSK 375/05 oraz wyrok WSA w Poznaniu z dnia 13 czerwca 2013 r., I SA/Po 197/13.

14 Wyrok NSA z dnia 21 grudnia 2004 r., GSK 1187/04, wyrok WSA w Gliwicach z dnia 21 października 2014 r., I SA/Gl 26/14, wyrok WSA w Łodzi z dnia 3 kwietnia 2014 r., I SA/Łd 127/14. Podobnie: P. Ciszewski, W. Lachiewicz, B. Jakacka, L. LipiecWarzecha, A. Pawlikowska, Dotacje..., s. 51.

15 GSK 1187/04. 


\section{4.}

Podsumowując, poza wyżej wymienionymi argumentami, glosowany wyrok zasługuje na poparcie również ze względu na to, iż przeciwstawia się on postępującemu zjawisku dominacji przepisów imperatywnych w polskim systemie prawa. Stosunek prawnodotacyjny, pomimo postulatów doktryny ${ }^{16}$, wciąż nie doczekał się modelowego (standaryzacyjnego) uregulowania z uwzględnieniem praw i obowiązków obu jego stron. Dotacje oświatowe są obszarem, w którym najpełniej objawia się powyższy brak ustawowej standaryzacji stosunku prawnodotacyjnego, co znajduje swoje potwierdzenie w ogromnej liczbie orzeczeń organów nadzorczych i sądowych rozstrzygających o prawach i obowiązkach j.s.t. (jako organu dotującego) oraz niesamorządowej jednostki oświaty (jako beneficjenta dotacji). Dodatkową wadą stosunku dotacyjnego w obszarze oświaty (potęgującą niepewność beneficjenta dotacji) jest wciąż istniejący spór co do jego charakteru prawnego: cywilnego czy administracyjnego ${ }^{17}$. Normy prawa dotacyjnego, podobnie jak normy prawa podatkowego, wymagają przyzwoitej legislacji. Posługując się tezą orzeczenia TK dotyczącego standardów stanowienia prawa podatkowego ${ }^{18}$, można stwierdzić, iż stanowienie również prawa dotacyjnego „nie może być pułapką dla obywatela”. Stąd też, tak zasadnicza kwestia dla podmiotu prowadzącego niesamorządową jednostkę oświaty, jak podstawa obliczania stawki dotacji (obejmująca pojęcie „najbliższej gminy”, której wydatki są brane do jej wyliczenia), nie może być dla niego daną zmienną i niepewną, uniemożliwiającą planowanie swej działalności w zaufaniu do organu dotującego. Najkorzystniejszym rozwiązaniem dla beneficjentów dotacji w tym zakresie byłoby jednak, aby to ustawodawca zdefiniował pojęcie „najbliższej gminy”, gdyż to zapewniłoby mu stabilniejszą sytuację, niż w przypadku, gdy organ stanowiący j.s.t. pojęcie to definiuje samodzielnie w oświatowej uchwale dotacyjnej. Stabilizacji tej

16 T. Dębowska-Romanowska, Prawo finansowe. Część konstytucyjna wraz z częściq ogólnq, Warszawa 2010, s. 49, C. Kosikowski, Naprawa finansów publicznych w Polsce (przyczyny, metodologia, kierunki i propozycje), Białystok 2011, s. 131.

17 Zob. szerzej: A. Ostrowska, Spór o właściwość sądowq w sprawach ustalania wysokości dotacji oświatowych, "Finanse Komunalne" 2015, Nr 3, s. 5-16.

18 Orzeczenie TK z dnia 3 grudnia 1996 r., K 25/95, OTK 1996, Nr 6, poz. 52. 
natomiast w ogóle nie posiada, gdy to organ wykonawczy j.s.t. uznaniowo co roku dokonuje wyboru „najbliżej gminy”.

Rozpatrując zaś nieuwzględnienie przez NSA pozostałych zarzutów wobec uchwały Rady Miejskiej B., należy podkreślić, że odnoszą się one do technicznych warunków udzielania, rozliczania i kontroli wykorzystania (a obecnie również pobrania) dotacji, które organ stanowiący j.s.t., wykonując upoważnienie ustawowe, miał w pełni prawo w swej uchwale uszczegółowić. Należy podkreślić, że źródłem finansowania dotacji oświatowych (w zależności od rodzaju szkoły) są nie tylko środki pochodzące z subwencji oświatowej uzyskiwanej z budżetu państwa (co ma miejsce w przypadku niesamorządowych szkół podstawowych), ale również dochody własne j.s.t. (co ma miejsce w przypadku niepublicznych szkół dla dorosłych, w których nie jest realizowany obowiązek szkolny, a których dotyczył glosowany wyrok NSA). Dlatego też dana j.s.t. ma uprawnienie, a nawet obowiązek te dochody własne chronić, ustanawiając szczegółowy tryb ich rozliczania i kontrolowania.

\section{Bibliografia:}

Ciszewski P., Lachiewicz W., Jakacka B., Lipiec-Warzecha L., Pawlikowska A., Dotacje oświatowe, C.H. Beck, Warszawa 2015.

Dąbek D., Prawo miejscowe, Oficyna a Wolters Kluwer business, Warszawa 2007.

Dębowska-Romanowska T., Prawo finansowe. Część konstytucyjna wraz z częściq ogólnq, C.H. Beck, Warszawa 2010.

Kosikowski C., Naprawa finansów publicznych w Polsce (przyczyny, metodologia, kierunki i propozycje), Temida 2, Białystok 2011.

Ostrowska A., Spór o właściwość sq̨dowq w sprawach ustalania wysokości dotacji oświatowych, "Finanse Komunalne" 2015, nr 3, s. 5-16.

Wronkowska S., Zieliński M., Komentarz do Zasad techniki prawodawczej z dnia 20 czerwca 2002 r., Wydawnictwo Sejmowe, Warszawa 2012. 